\title{
TRADISI MEGALITIK DAN SISTEM NILAI BUDAYA MALUKU
}

\author{
Marlyn Salhuteru dan Lucas Wattimena \\ Balai Arkeologi Ambon \\ J1. Namalatu - Latuhalat, Kota Ambon 97118 \\ Email : balar.ambon@yahoo.co.id
}

\begin{abstract}
Abstrak
Kepulauan Maluku memiliki tinggalan arkeologis yang sangat kaya dan melimpah tersebar ke seluruk pelosok daerah di Maluku. Kekayaan sumberdaya budaya arkeologis menjadikan substansi identitas sebagai bangsa yang berbudaya, berbangsa dan bertanah air.

Tradisi megalitik merupakan suatu sumberdaya budaya arkeologi yang perlu untuk dijaga, dipelihara serta dirawat. Sebab tradisi megalitik masyarakat Maluku adalah kesatuan sistem nilai budaya yang berkelanjutan (tradisi berlanjut) yang selalu terintegrasi dalam siklus masyarakat Maluku yang dahulu, sekarang maupun pada masa-masa mendatang.
\end{abstract}

Kata kunci : sistem nilai budaya, tradisi megalitik, masyarakat dan kebudayaan

\begin{abstract}
The Moluccas archipelago has a rich archaeological remains all over this region. This archaeological resources may serves as a reflection of the identity as a cultural nation. The megalithic tradition is one of the archaeological resources that need to be protected, preserved and conserved. It was based on the fact that the megalithic tradition in the Moluccas community is a cultural value system that have been integrated in the community in this region accross generation.

Keywords: cultural value system, megalithic tradition, community and culture
\end{abstract}

\section{PENDAHULUAN}

Penulisan ini merupakan kewajiban penulis sebagai peneliti pada Balai Arkeologi Ambon dalam memberikan gambaran atas hasil-hasil penelitian yang telah dilakukan selama ini oleh Balai Arkeologi Ambon. 
Melihat luas cakupan pembahasan makalah ini, maka penulis hanya membatasi pada Tinggalan-tinggalan arkeologi (megalitik) sebaga sistem nilai budaya, pada hasil-hasil penelitian yang pernah dilakukan oleh Balai Arkeologi Ambon dalam kurun waktu 10 tahun. Oleh Karena itu paparan makalah ini hanya merupakan perspektif gagasan konseptual manusia dan budaya dalam tradisi megalitik.

Sejak berdirinya Balai Arkeologi Ambon dari tahun 1995 sampai sekarang sebagai Unit Pelaksana Teknis Pusat mempunyai tugas, pokok dan fungsi sebagai lembaga penelitian dengan wilayah kerja Maluku dan Maluku Utara telah melaksanakan berbagai penelitian. Penelitianpenelitian yang dilakukan oleh peneliti Balai Arkeologi menuju pada 3 tema besar yaitu; 1) Prasejarah, Kolonial dan Islam, meskipun ada tema-tema penting lainnya yang korelasi tanpa menghilangkan hubungan itu sendiri, sehingga sifatnya temporal parsial.

Tulisan ini memberikan gambaran seperti apa tradisi megalitik di Maluku dan bagaimana implikasi dalam kehidupan sosial budaya sekarang dan masa-masa yang akan datang. Hasil-hasil penelitian dibatasi hanya pada Pulau Seram, Buru, dan Ambon Lease.

\section{LATAR BELAKANG}

Studi etnoarkeologi adalah suatu cabang studi arkeologi yang memanfaatkan data etnografi sebagai analogi untuk membantu memecahkan masalah-masalah arkeologi. kajian ini didasarkan penelaran induktif sehingga kedudukannya hanya bersifat memberikan contoh (sampel) untuk interprestasi, menyajikan kemungkinan awal (priorprobability), atau menilai kelayakan hipotesis. Hasil kajian etnoarkeologi tidak memberikan pembuktian benar atau tidaknya hipotesanya, karena bukan merupakan uji penyimpulan induktif. Kajian itu hanya perluasan dari proses induktif itu sendiri atau abduksi. Jadi kajian etnoarkeologi bukannya untuk menjelaskan gejala yang teramati saat ini (data etnografi), tetapi sekedar memberikan gambaran kemungkinan adanya persamaaan antara gejala budaya masa lampau dengan budaya masa kini, atau sebagai argumentasi penghubung (bridging arguments) dalam rangka uji hipotesis, model, dan teori (Sukendar dkk 1999 : 188).

Secara geografis, Kepulauan Maluku adalah bagian dari Zona Wallasea yang dalam sejarahnya tidak pernah bergabung dengan Paparan Sunda maupun Paparan Sahul. Karena itu, proses penghunian kepulauan ini oleh manusia pasti melibatkan pelayaran dari satu pulau ke pulau lainnya. Hingga dasawarsa lalu, awal penghunian kepulauan Maluku lebih banyak diasumsikan dilakukan oleh manusia dari Paparan Sunda ke arah timur melalui Sulawesi, kepulauan Banggai, Sula, kemudian bercabang ke utara menuju Halmahera hingga Papua Utara, dan ke arah selatan menuju Obi, Seram, Ambon, dan Aru hingga ke Paparan Sahul (Daud 2009 : Seminar Sail Banda).

Berdasarkan hal di atas, maka tinggalan-tinggalan budaya megalitik di kepulauan Maluku secara eksplisit dapat dikatakan bahwa berasal dari hasil-hasil (ide, gagasan, cipta, karsa) manusia yang berproses migrasi pada saat itu dan sifatnya berkelanjutan.

Megalitik berasal dari kata Mega yang berarti besar dan lithos yang berarti batu. Oleh sebab itu megalitik adalah bangunan yang dibuat dari batu besar, yang terjadi selama masih berhubungan dengan hal-ha yang berkaitan kegiatan masyarakat sebelum ada pengaruh hindu-budha dan islam jenis-jenis bangunan megalitik terdiri dari (Sukendar dkk : 83) :

a. Sarkofagus adalah bangunan yang terdiri dari wadah dan tutup dengan bentuk dan ukuran yang sama (simetris).

b. Dolmen yaitu meja batu, susunan batu yang terdiri dari sebuah batu yang ditopang oleh beberapa buah batu sehingga menyerupai meja

c. Peti batu peti berbentuk empat persegi panjang yang disusun oleh lempengan-lempengan batu yang terdiri atas lempengan dasar.

d. Pundek berundak struktur bangunan yang disusun berundak, baik atas maupun ke belakang.

e. Tong batu wadah berbentuk silinder dengan tutup berbentuk bundar berukuran besar.

f. Bilik batu adalah bilik atau ruangan (sebuah atau lebih) yang dindingdindingnya terdiri dari lempengan batu yang lebar dan tebal.

g. Menhir sebuah monolit, baik yang dikerjakan maupun tidak, dengan dimensi panjang, lebar, tebal.

h. Lesung Batu adalah sebuah monolit batu yang dikerjakan atau tidak, dan pada permukaaan atas diberikan lubang yang berbentuk oval.

$i$. Pelinggih susunan batu yang terdiri dari sebuah alasa dan sandaran.

$j$. Batu dakon batu monolit yang dikerjakan atau tidak.

$k$. Batu temu gelang beberapa batu yang disusun hingga membentuk lingkaran

l. Tetralit beberapa batu yang disusun persegi

Tradisi megalitik untuk wilayah Maluku hanya ditemukan beberapa, yaitu dolmen dan menhir dan ada juga Negeri Lama (pemukiman kuno). Hampir rata-rata semua kampung/desa/negeri yang ada di wilayah Maluku memiliki tinggalan budaya ini. Hanya saja yang membedakan satu kampong/negeri/desa dengan yang lain adalah nilainilai sosial budaya yang terkandung dalam konstruktif bangunan tersebut. 


\section{PERMASALAHAN}

Penulis dalam hal ini memberikan perspektif etnoarkeologi terhadap penelitian-penelitian arkeologi yang pernah dilaksanakan oleh Balai Arkeologi Ambon dengan mengacu pada salah satu tema di atas, yaitu Prasejarah. Perkembangan tradisi budaya di Maluku tak dapat dilepaspisahkan dengan nilai-nilai sosial budaya yang konstruktif, sehingga masyarakat yang hidup dalam lingkaran tradisi itu menjadi lebih kuat atas dasar kesatuan sistem nilai budaya. Berdasarkan uraian latar belakang di atas, maka yang menjadi foc

kus permasalahan adalah bagaimana tradisi megalitik sebagai sistem nilai budaya maluku.

\section{TUJUAN PENELITIAN}

Penulisan ini bertujuan dalam rangka memahami dan mengetahui konstruksi perspektif konseptual sistem nilai budaya dalam tradisi megalitik di Maluku.

\section{MANFAAT PENELITIAN}

Penelitian diharapkan bermanfaat bagi kemajuan dan peningkatan bahan-bahan penelitian lanjutan dengan tema-tema sosial budaya serupa maupun lainnya.

\section{LANDASAN TEORI}

\section{Konsep Kebudayaan}

Konsepsi antropologis tentang budaya merupakan salah satu gagasan paling penting dan berpengaruh dalam pemikiran abad ke 20. Para pakar antropologi belum tepat sekali, atau benar-benar konsisten, dalam memakai konsep yang penting ini. Beberapa upaya untuk memberikan definisi menunjukan beberapa segi budaya :

1. Taylor mengatakan bahwa kebudayaan adalah Suatu keseluruhan kompleks yang meliputi pengetahuan, kepercayaan, seni, kesusilaan, hokum, adat istiadat, serta kesanggupan dan kebiasaan lainnya dipelajari oleh manusia sebagai anggota masyarakat.

2. Kroeber dan Kluckhkon : pola, eksplisit, dan implisit tentang dan untuk perilaku yang dipelajari dan diwariskan melalui symbol-simbol, yang merupakan prestasi khas manusia, termasuk perwujudan dalam benda-benda budaya.

3. Kluckhkon dan Kelly : (semua) rancangan hidup yang tercipta secara historis, baik yang eksplisit maupun implicit, rasional maupun irasional dan nonrasional, yang potensial untuk prilaku manusia (Keesing $1981: 68$ ).

Di lain pihak Ogburn (Johnson 1986 : 112) kebudayaan meliputi kumpulan kebiasan-kebiasan serta pola-pola instutisional yang merupakan bagian dari warisan social yang diturunkan dari satu generasi ke generasi berikutnya dan ditiru sebagai hasil dari proses pengaruh sosial. Kebudayaan seyogyanya memiliki 3 konsep penting, yakni : asimilasi, evolusi dan akulturasi. Pandangan perspektif seperti ini kiranya dijadikan patokan dalam melihat kebudayaan secara universal dan dapat memilah-milah kebudayaan secara baik agar indikasi ke depan bagi masyarakat pun baik adanya. Namun ada juga kelemahan seperti ini; identitas, budaya, social menjadi patokan utama, yang mana sebenarnya kebudayaan suatu bangsa/ masyarakat. Koentjaraningrat (1974:12) kebudayaan terdiri dari 7 (unsur) yaitu sistem religi dan upacara keagamaan, sistem dan oragnisasi kemasyarakatan, sistem pengetahuan, bahasa, kesenian, sistem mata pencaharian hidup, sistem teknologi dan peralatan. Pandangan antropologi pada dasarnya melihat keseluruhan konsep secara menyeluruh dengan perspektif social budaya yang ada pada masyarakat. Realita yang kerap terjadi di lapangan merupakan realitas social yang perlu kita bina dan jaga sedemikian rupa sehingga membentuk suatu kesatuan konsep-konsep kebudayaan.

\section{Konsep Sistim Nilai Budaya}

Menurut Sztompka (2008 : 2) Pemikiran tentang sistem merupakan satu kesatuan yang kompleks, terdir dari berbagai antar hubungan dan dipisahkan dari lingkungan sekitarnya oleh batas tertentu. Organisme jelas merupakan contoh sebuah sistem, begitu pula molekul, bangunan, planet, dan galaksi. Fungsionalisme sebagai perspektif teoretik dalam antropologi bertumpu pada analogi dengan organisme Artinya, ia membawa kita memikirkan sistim social budaya sebagai semacam organisme, yang bagian-bagiannya tidak hanya saling berhubungan melainkan juga memberikan andil bagi pemeliharaan, stabilitas, dan kelesatarian hidup organisme itu. Dengan demikian dasar semua penjelasan fungsional ialah asumsi (terbuka maupun tersirat) bahwa semua sistem budaya memiliki syarat-syarat fungsional tertentu untuk memungkinkan eksistensinya. 
Atau, sistim budaya memiliki kebutuhan (mungkin dikatakan sebagai kebutuhan sosial ala Radcliffe-Brown, atau diungkapkan dalam peristilahan biologis individual ala Malinowski) yang semuanya harus dipenuhi agar sistim itu dapat bertahan hidup. Dapatlah diduga bahwa jika kebutuhan sistim fungsional itu tidak dipenuhi maka sistem itu akan mengalami disintegrasi dan mati. Atau, ia akan berubah menjadi sistim lain yang berbeda jenis. Maka dalam hal in institusi, kegiatan budaya, dan kompleks kultural lainya, dipahami atau dijelaskan bukan hanya sebagai spesifikasi hubungan dengan sesuatu sistim yang lebih besar dan mengimplikasikan hal-hal tersebut. Hendak ditunjukkan pula bahwa hubungan tadi ikut berperan memelihara sistim besar itu atau sebagian tertentu darinya. Dalam metode komparatif itu perlu dipergunakan suatu konsep dasar yang menjadi kesatuan dalam analisa komparatif, yaitu konsep "struktur sosial", atau social structure Radcliffe-Brown (Koentjaraningrat 1987: 179). Radcliffe-Brown juga mengakui bahwa perkembangan ke arah kematangan dari suatu ilmu sosial dengan metodologi ilmu alam tidak akan dapat terjadi dengan cepat, karena ada empat buah faktor yang menghambatnya, yaitu:

1. sifat multipal," yaitu jumlah yang besar dan beraneka warna dari gejala-gejala sosial

2. Cara berpikir historis yang telah berakar dalam alam pikiran kebanyakan sarjana ilmu sosial

3. Konsep-konsep psikologi yang seringkali juga sudah berakar dalam alam pikiran kebanyakan sarjana ilmu sosial, padahal konsep-konsep psikologi hanya dapat menerangkan sebabmusabab tingkahlaku seseorang, tetapi tidak mungkin dapat menerangkan sebab-sebab dari suatu gejala sosial

4. Penelitian ilmu-ilmu sosial terlampau banyak dipengaruhi oleh pandangan umum yang menghendaki jawaban segera terhadap suatu masalah sosial yang mendesak, atau yang menghendaki fakta untuk melaksanakan suatu tindakan atau untuk menyusun suatu kebijaksanaan. Radcliffe-Brown (Koentjaraningrat 1987: 179-180)

\section{METODE PENELITIAN}

Metode yang digunakan adalah studi kepustakaan.

\section{KERANGKA PIKIR}

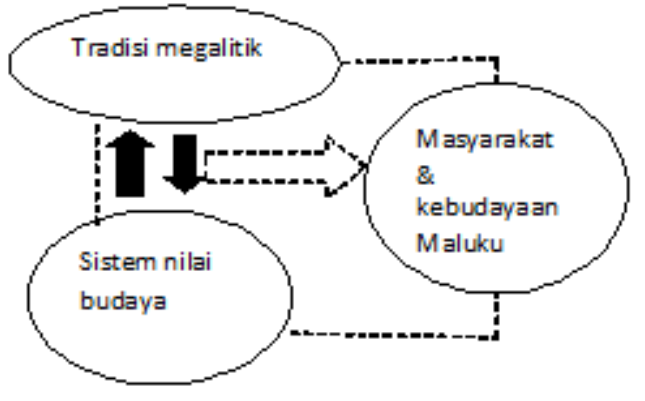

Gambar alur kerangka pikir penelitian

\section{HASIL PENELITIAN}

Seperti yang telah dijelaskan diatas, bahwa gagsan konseptual in merupakan ringkasan penelitian penelitian yang pernah dilakukan oleh Balai Arkeologi Ambon dalam kurun waktu sepuluh tahun, maka dibawah ini diuraikan beberapa hasil penelitian Tradisi Megalitik antara lain :

\section{Negeri/desa Aboru, Kecamatan Haruku Kabupaten Maluku} Tengah

\section{a. Situs Negeri Lama Ama Ira}

Situs ini terletak sekitar $6 \mathrm{Km}$ dari pusat desa Aboru, tepatnya terletak di pedalaman. Untuk mencapai situs ini harus melewati medan yang cukup berat dan hanya dapat dijangkau dengan berjalan kaki. Situs ini terletak di atas puncak bukit di antara perbukitan karang dan gua-gua karang. Vegetasi sekitarnya ditumbuhi tanaman liar dan diselingi beberapa tanaman milik penduduk seperti pohon pala, kenari, umbi-umbian, cengkeh dan sagu. Sisa bukti kehidupan manusia yang masih dapat diamati di situs ini adalah pagar batu, batu asah, bekas ponadasi bangunan, fragmen tembikar, dan fragmen botol kaca.

\section{b. Pagar Batu}

Merupakan susunan batu alam setinggi kurang lebih 1 meter yang mengelilingi lokasi negeri lama. Kondisinya tidak terawat dan sudah banyak yang runtuh sehingga hanya tinggal beberapa meter 
saja yang dapat diamati. Melihat bahannya, diperkirakan bahan baku berupa batuan diambi langsung dari sekitar lokasi tersebut. Medan yang sukar dijangkau karena berada di tengah-tengah tebing karang sehingga tidak mungkin bahan batuan diambil dari tempat lain, melainkan memanfaatkan bahan batuan yang ada.

\section{c. Batu Asah}

Batu asah atau yang oleh penduduk setempat disebut batu goso, merupakan sebuah batu datar dengan bentuk persegi empat denagn ukuran 120,5 Cm x $24 \mathrm{Cm}$. Pada salah satu sisinya terlihat lebih halus / mengkilat akibat gosokan senjata tajam. Batu asah difungsikan oleh masyarakat sekitar untuk mengasah senjata tajam seperti parang, pisau, tombak, dan sebagainya.

\section{d. Batu Datar}

Sebuah batu datar ditemukan kurang lebih sekitar 5 meter dari lokasi batu asah. Batu datar di beberapa tempat di Maluku difungsikan sebagai betu meja atau dolmen. Namun di Aboru, terjadi perubahan fungsi dari batu datar tersebut. Di lokasi ini batu datar oleh masyarakat setempat difungsikan sebagai tempat menumbuk kenari.

\section{. Bekas Pondasi Bangunan}

Beberapa meter dari pagar batu, ditemukan sebuah susunan batu karang, yang diperkirakan sebagai pondasi bangunan. Sisa-sisa bangunan sudah tidak nampak, disuga bangunan tersebut terbuat dari bahan yang mudah rusak seperti abmbu atau kayu.

\section{Air Papaya (Dusun Airpapaya) Dan Waiyasel, Kecamatan Luhu} Kabupaten Seram Bagian Barat

\section{a. Negeri Lama Air Papaya}

Lokasi negeri lama Airpapaya berada pada ketinggian $200 \mathrm{~m}$ dpl. Negeri lama Airpapaya saat ini diperuntukkan sebagai lahan perkebunan cengkeh yang luas. Oleh karena itu sangat sulit mengidentifikasi lahan ini sebagai situs bekas permukiman kuno masyarakat pada masa lampau. Demikian juga mnegenai batas situs, berdasrkan survei sangat sulit melihat batas dan luasan negeri lama Air Papaya.Namun berdasarkan temuan arkeologis seperti gerabah dan keramik asing yang tersebar meski dengan kuantitas yang minim, ciri hunian masa lampau dapat dijejaki. Minimnya data yang ditemukan kemungkinan disebabkan karena areal ini telah teraduk akibat aktifitas masyarakat mengolah kebun cengkeh. Fragmen gerabah yang ditemukan adalah gerbah polos dan relatif tipis, dari bahan yang halus. Dengan demikian menunjukkan adanya teknologi yang lebih maju. Dari identifikasi bentuk, memperlihatkan ciri wadah yang dipergunakan seharihari. Di beberapa titik areal menuju negeri lama yang telah digunakan menjadi untuk kebun penduduk pada ketinggian 160 $\mathrm{m}$ dpl juga banyak ditemui sebaran gerabah dan keramik asing yang cukup padat. Temuan lainnya yang cukup menarik, yakni sebuah benda yang menyerupai giring-giring (istilah Jawa), yakni alat terbuat dari logam berbentuk bulat berwarna perak, terdapat lubang horizontal dan didalamnya terdapat biji dari logam atau batu yang menimbulkan bunyi jika digoyangkan. Kemungkimnan alat ini sebagai salah satu perlengkapan upacara adat atau upacara ritual. Menurut penduduk, benda ini ditemukan pada saat mereka mengolah kebun cengkeh di lokasi negeri lama Airpapaya.

\section{b. Wayase}

\section{Kampung Kuno/Negeri Lama Wayase}

Kampung kuno atau negeri lama Wayase, terletak di perbukitan dengan ketinggian $250 \mathrm{M}$ dpl. Tempat ini berjarak $2 \mathrm{Km}$ dari dusun Airpapaya atau mendekati perbatasan desa Airpapaya dengan desa Wayase. Secara administratif situs ini sebenarnya sudah masuk dalam wilayah Dusun Wayase. Masyarakat menyebutnya sebagai Kota Mulu'. Daerah ini merupkan padang datar dengan luas diperkirakan mencapai $200 \mathrm{M}^{2}$.Pada areal seluas 100 × $50 \mathrm{M}$, ditemukan sebaran keramik asing dan gerabah yang terkonsentrasi. Di duga areal inilah adalah pusat kampung negeri lama Wayase. Berdasarkan identifikasi bentuknya, gerabah yang ditemukan di situs ini pada umumnya merupakan wadah, diantaranya tempayan, mangkuk dan piring. Bentuk wadah ini umumnya dipergunakan sebagai alat sehari-hari Ditemukan pula beberapa sampel gerabah hias. Yang menarik salah satunya berupa mangkuk berkaki yang memperlihatkan bentuk semacam pedupaan. 
Diduga kuat temuan ini khusus digunakan sebagai alat upacara keagaamaan oleh masyarakat. Mangkuk ini merupakan wadah

\section{Tabel 1.}

Hasil Analisis fragmen gerabah

\begin{tabular}{|c|c|c|c|c|}
\hline NO & $\begin{array}{l}\text { BAGIAN } \\
\text { TEMUAN }\end{array}$ & POLA HIAS & WARNA & TEKNIK HIAS \\
\hline 1 & BADAN & POLOS & GRAYS RED & \\
\hline 2 & BADAN & HIAS & GRAYS RED & GORES \\
\hline 3 & TEPIAN & POLOS & DULL & \\
\hline 4 & BADAN & HIAS & REDISH BROWN & GORES \\
\hline 5 & BADAN & POLOS & PALE REDISH & \\
\hline 6 & BADAN & POLOS & RED & \\
\hline 7 & TEPIAN & POLOS & REDISH & \\
\hline 8 & DASAR & POLOS & DULL ORANGE & \\
\hline 9 & TEPIAN & POLOS & BROWN & \\
\hline 10 & DASAR & POLOS & GRAYS RED & \\
\hline 11 & BADAN & POLOS & REDISH BROWN & \\
\hline 12 & BADAN & POLOS & RED & \\
\hline 13 & BADAN & POLOS & DULL RED.BR & \\
\hline 14 & TEPIAN & POLOS & RADISH BROWN & \\
\hline 15 & TEPIAN & POLOS & DULL & \\
\hline 16 & BADAN & POLOS & DULL & \\
\hline 17 & BADAN & POLOS & REDISH & \\
\hline 18 & BADAN & POLOS & REDISH & \\
\hline 19 & BADAN & POLOS & REDISH BROWN & \\
\hline 20 & DASAR & HIAS & PALE & GORES / CUKIL \\
\hline 21 & TEPIAN & POLOS & BROWNISH GREY & \\
\hline 22 & TEPIAN & POLOS & REDISH BROWN & \\
\hline 23 & DASAR & POLOS & REDISH BLACK & \\
\hline 24 & TEPIAN & POLOS & V DARK BROWN & \\
\hline 25 & BADAN & POLOS & BROWNIS GREY & \\
\hline 26 & TEPIAN & POLOS & GRAYISH RED & \\
\hline 27 & BADAN & POLOS & REDDISH & \\
\hline
\end{tabular}

Sumber : Balai Arkeologi Ambon, 2007 dengan pola hias yang menunjukkan motif hias asli Maluku. Pola hias menunjukkan corak asli Maluku berupa motif geometris, garis-garis dan garis lengkung setengan lingkaran dengan panel-panel lingkaran dan motif hias bintik-bintik. Tehnik hias menggunakan tehnik gores dan cukil. Pada umumnya gerabah yang ditemukan memiliki ukuran ketebalan yang tipis, dengan bahan pembuatan yang lebih halus. Ciri ini menunjukkan perkembangan tehnologi pembuatan gerabah yang lebih maju. Temuan fragmen keramik asing, juga merupakan wadah yang dipergunakan sehari-hari antara lain jenis mangkuk besar, mangkuk kecil dan piring serta cawan. Warna glasir pada umumnya putih kebiru-biruan. Warna bahan putih keabu-abuan, dengan motif hias flora berwarna biru. Jenis keramik ini berasal dari China, kemungkinan dari masa Dinasti Ming dan Ching. Baik tembikar maupun keramik asing, merupakan barang dari luar. Gerabah di situs negeri lama Airpapaya maupun Wayase, kemungkinan berasal dari daerah lain di Maluku, mengingat bahan baku tidak memungkinkan dari lokasi setempat yang banyak mengandung batuan gamping disamping tradisi pemakaian dan pembuatan gerabah tidak ada di kedua dusun tersebut. Jika melihat pola hias gerabah yang menunjukkan corak atau gaya hiasan asli Maluku, kemungkinan berasal dari daerah lain di Maluku yang sebelumnya telah mengenal tradisi pembuatan gerabah seperti di Pulau Saparua maupun di daerah Maluku Tenggara.Adanya pemanfatan gerabah dari daerah luar di Maluku dalam kehidupan sehari-hari masyarakat negeri lama Airpapaya dan Wayase kemungkinan pada masa perkembangan perdagangan lokal dengan sistem barter atau jual beli dengan mata uang dengan daerah lain.

\section{Batu Meja / Batu Pamali}

Lokasi temuan batu meja terletak sekitar 160 meter dari negeri lama Wayase (Kota Mulu'). Melihat posisinya, masih terletak di areal kampung lama, mengingat jarak yang relatif dekat, dengan intensitas temuan gerabah yang masih dijumpai di titik-titik jalur menuju lokasi batu meja dari kampung lama. Disekeliling batu, disusun batu gamping yang menjadikan semacam pembatas yang berjarak hanya sekitar $50 \mathrm{~cm}$ dari 
posisi batu meja. Di sekitar batu meja juga nampak pagar batu atau benteng yang hanya nampak sebagai gundukan tanah ditumbuhi semak belukar. Benteng/pagar batu yang masih nampak berada di sebelah utara dan timur batu meja dengan jarak sekitar 15 meter. Di sekitar batu meja merupakan areal semak belukar dan pohon-pohon besar. Melihat temuan berbagai sesajen di sekeling betu meja serta adanya pecahan tempayan tanah liat, memunjukkan bahwa batu meja tersebut masih dimanfaatkan penduduk sekarang sebagai sarana upacara ritual. Hubungannya dengan batu meja, melihat konteks temuannya bisa disimpulkan bahwa tradisi megalitiik masih berlangsung terus sejak masa awal pengaruh Islam hingga saat ini.

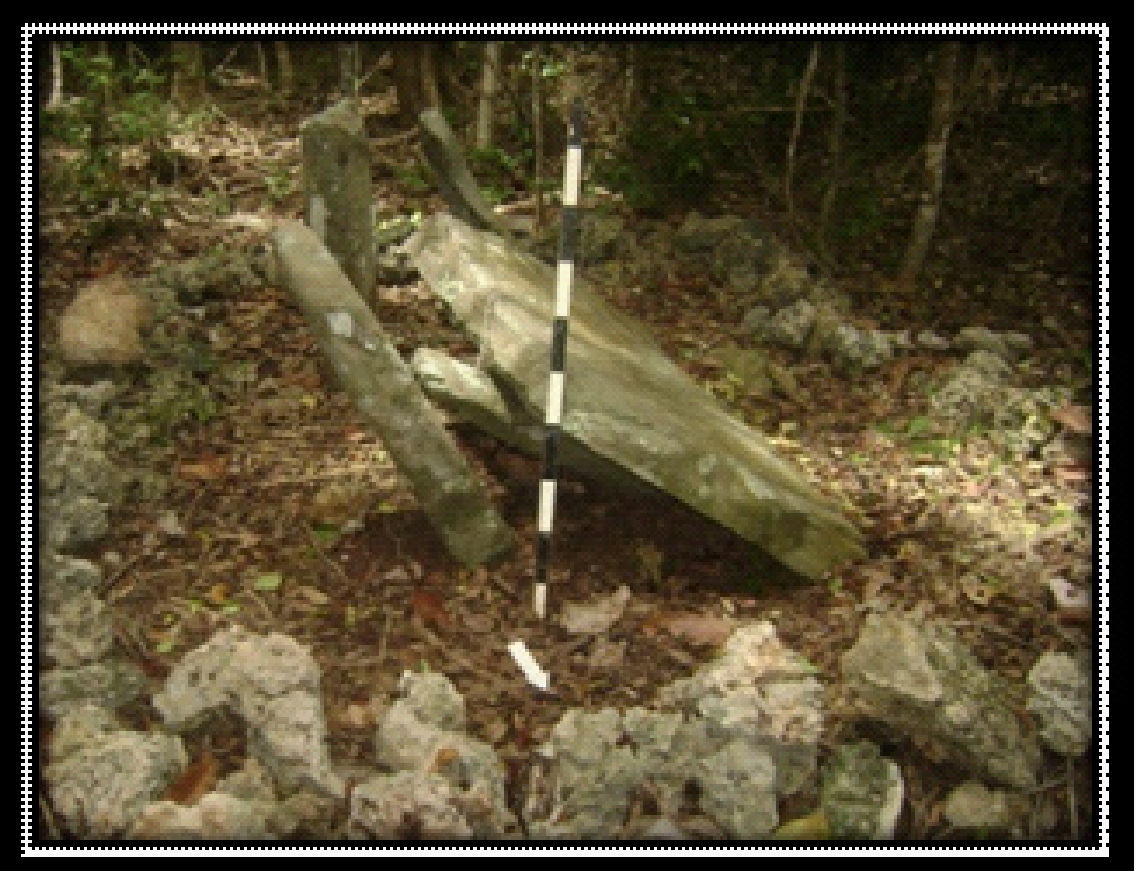

Gambar 1. Batu Meja Di Kota Mulu
3. Das (Daerah Aliran Sungai) Tala, Kabupaten Seram Bagian Barat

a. Situs Pemukiman Negeri Lama Sowe

Negeri Lama Desa Sumieth Pasinaro disebut Sowe terletak di puncak gunung yaitu Gunung Kepala Tupapa yang dialiri oleh Sungai Ilalei. Situs ini dapat dijangkau dari desa dengan menggunakan kendaraan roda empat selama kurang lebih 30 menit melalui jalan proyek. Kemudian dilanjutkan dengan berjalan kaki kira-kira selama 1 jam perjalanan. Situs negeri lama desa Sumieth Pasinaro menyimpan beberapa tinggalan arkeologis berupa : dolmen / batu meja, alat batu, fragmen keramik asing, fragmen gerabah, fragmen botol kaca, dan cangkang moluska. Dolmen/batu meja Ada dua buah dolmen yang letaknya berdekatan, masing-masing dolmen dapat dideskripsikan sebagai berikut :

\section{Dolmen I}

Berbentuk persegi empat tidak beraturan, ditopang oleh empat buah batu berdiri berbentuk persegi empat sebagai kakinya. Pada permukaan dolmen terdapat lubang-lubang kecil berjumlah empat buah, berdiameter 3 sampai $5 \mathrm{~cm}$. Menurut masyarakat setempat, lubang-lubang pada permukaan dolmen

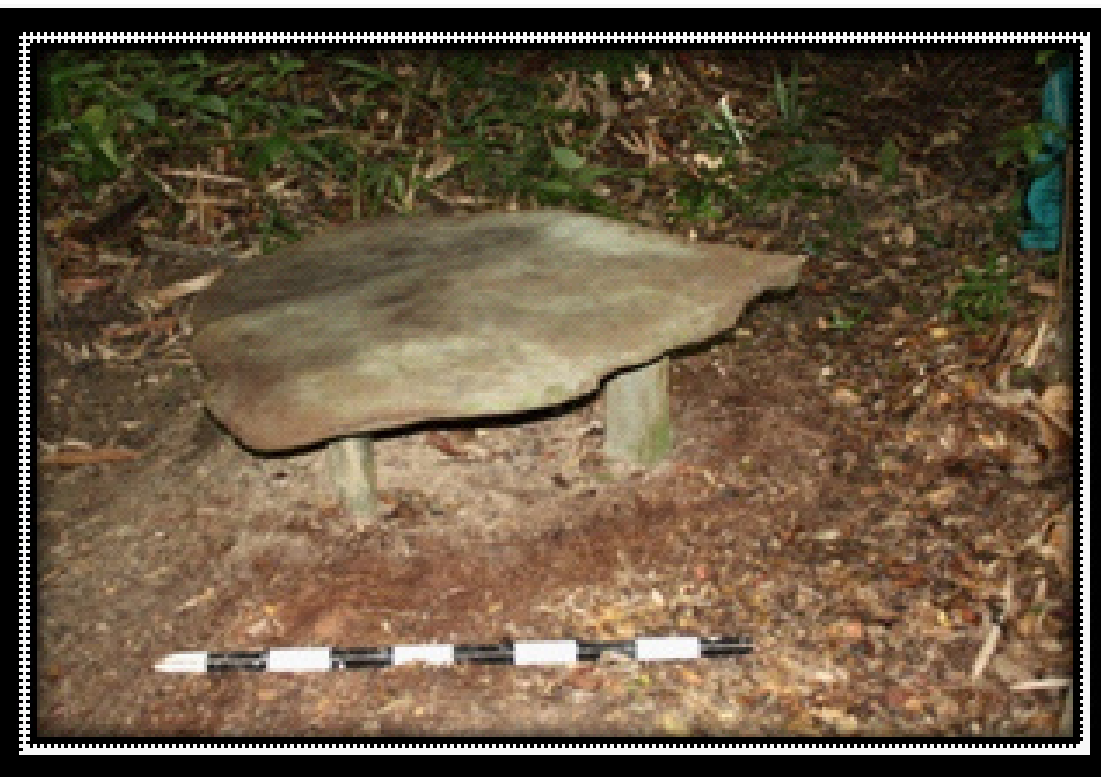

Gambar 2. Dolmen di situs negeri lama Sowe 
tersebut berfungsi sebagai tempat meletakan sirih dan pinang pada saat dolmen difungsikan dalam suatu ritual tertentu.

2. Dolmen II

Bentuknya tidak beraturan, dengan ukuran yang sedikit lebih besar dibanding dolmen I. Awalnya dolmen ini disangga oleh empat buah batu berdiri sebagai kakinya, namun karena beberapa sebab, dolmen II ini telah runtuh ke tanah.

Batu berdiri yang diduga merupakan kaki dolmen telah berpindah dari posisi dolmen sekitar 20 meter. Tidak jauh dari posisi batu berdiri ini terdapat tiga buah batu lainnya, yang juga diduga merupakan kaki dolmen. Tinggi kaki dolmen rata-rata sekitar $45 \mathrm{~cm}$, dengan ketebalannya antara $6-10 \mathrm{~cm}$

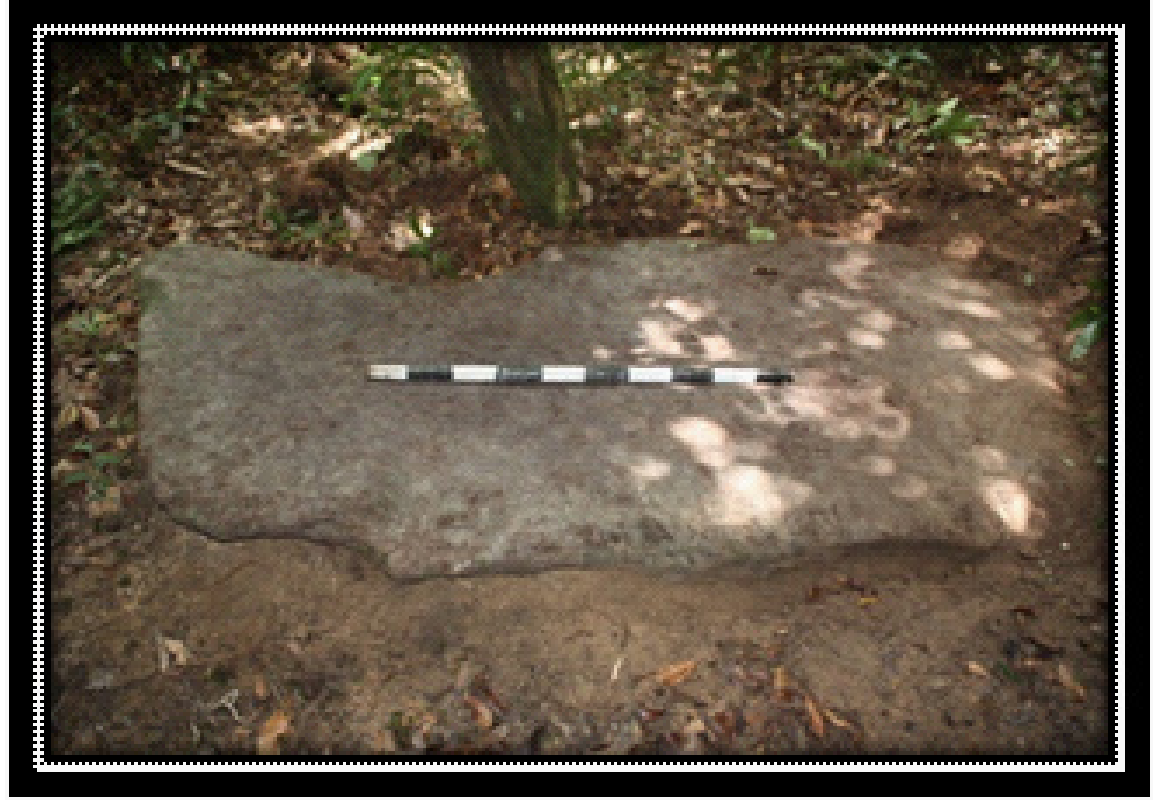

Gambar 3. Dolmen yang terdapat di situs negeri lama Sowe

\section{PEMBAHASAN}

\section{Tradisi Megalitik}

Tradisi adalah kebiasaan turun-temurun sekelompok masyarakat berdasarkan nilai-nilai budaya masyarakat yang bersangkutan. Tradisi memperlihatkan bagaimana anggota masyarakat bertingkah laku, baik dalam kehidupan yang bersifat duniawi maupun terhadap hal-hal yang bersifat baik atau keagamaan. Di dalam tradisi diatur bagaimana manusia berhubungan dengan manusia lain, dan bagaimana manusia bertindak dengan kelompok manusia lain, dan bagaimana manusia bertindak terhadap lingkungannya, dan bagaimana perilaku manusia terhadap alam. Berbicara mengenai tradisi, hubungan antara masa lalu dan masa kini haruslah lebih dekat (Piotr Sztompka 2007 : 69).

Batu datar yang pada bagian atasnya terdapat bekas-bekas asahan merupakan tinggalan dari jaman megalitik yang bersifat universal. Batu asah umumnya berperan dalam upacara-upacara tertentu dalam masyarakat seperti upacar sebelum perang, serta upacara untuk menolak wabah penayakit.

Tradisi mencakup kelangsungan masa lalu di masa kini ketimbang sekadar menunjukkan fakta bahwa masa kini berasal dari masa lalu. Kelangsungan masa lalu di masa kini mempunyai dua bentuk : material dan gagasan, atau objektif dan subjektif. Menurut arti yang lebih lengkap, tradisi adalah keseluruhan benda material dan gagasan yang berasal dari masa lalu namun benar-benar masih ada kini, belum dihancurkan, dirusak atau dilupakan. Di sini tradisi hanya berarti warisan, apa yang benar-benar tersisa dari masa lalu. Seperti yang dikatakan oleh Shils (dalam Piotr Sztompka 2007 : 70), tradisi berarti segala sesuatu yang disalurkan atau diwariskan dari masa lalu ke masa kini. Yang terpenting dalam memahami tradisi adalah sikap atau orientasi pikiran tentang benda material atau gagasan yang berasal dari masa lalu yang dipungut oleh orang masa kini. Sikap atau orientasi ini menempati bagian khusus dari keseluruhan warisan histories dan mengangkatnya menjadi tradisi.

Tidak jauh dari lokasi batu asah, terdapat sebuah batu datar lainnya yang oleh masyarakat difungsikan sebagai temapat untuk menumbuk kenari (buah yang daging buahnya dilapisi cangkang yang amat keras sehingga untuk memperoleh daging buahnya, terlebih dahulu cangkangnya harus dilepas dengan cara ditumbuk). Nampak adanya pergesaran fungsi dari fungsi sakral yaitu batu datar atau dolmen sebagai tempat upacara ke fungsi profan. Namun demikian, keberadaan batu datar menandakan bahwa di lokasi tersebut pernah berlangsung tradisi megalitik.

Pagar batu yang ditemukan di situs Negeri lama Ama Ira oleh masyarakat setempat disebut sebagai benteng. Namun, mengingat peninggalan ini berasal dari zaman prasejarah, maka rasanya istilah 
benteng belumlah tepat. Kata benteng umunya diistilahkan sebagai bangunan yang berfungsi sebagai tempat pertahanan untuk menghindari serangan musuh. Di beberapa daerah di Indonesia dapat dijumpai pagar batu serupa. Di timor misalnya pagar batu disebut Ksadan yang berfungsi sebagai tempat upacara. Dengan demikian maka keberadaan pagar batu di desa Aboru erat kaitanya dengan tradisi megalitik. Pagar batu merupakan batas antara daerah sakral dan profan. Asumsi ini diperkuat dengan ditemukannya batu datar sebgai alat upacara tidak jauh dari pagar batu tersebut.

\section{Dolmen/Menhir Dan Negeri Lama; Kesatuan Sistim Nilai Budaya}

Masyarakat Maluku sangat memegang teguh tradisi leluhur yang telah diturunkan secara generasi, hingga sekarang ini. Tradisi-tradisi ini berkelanjutan dalam tatanan sistem nilai social budaya yang kompleks dengan ketajaman induktif-induktif dalam masyarakat. Menurut F. L. Cooley (1987 : 106) masyarakat Maluku memahami budaya itu sebagai totalitas yang utuh dan apa yang disebut adat. Adat oleh masyarakat Maluku mencakup semua yang ada dalam cakupan kebudayaan tadi, dan tidak terbatas pada tradisi dan kebiasaan-kebiasaan, hal itu memperlihatkan mengapa masyarakat Maluku sangat kuat berpegang pada adatnya, baik dalam dimensi ritus/upacara maupun pada tatanan nilai-nilai.

Dolmen, menhir dan negeri lama merupakan satu kesatuan sistem nilai budaya yang tak terpisahkan antara satu dengan yang lainnya. Dalam kesatuan sistem ini terdapat sub-sub sistem yang menjaga keseimbangan (equilibrium). Misalnya dalam acara-acara adat, sebagai contoh pelantikan Raja negeri Waraka, seorang Raja dilantik biasanya masyarakat waraka membawa menuju ke negeri lama untuk diperkenalkan kepada para nenemoyang dan kemudian menuju baileo, setelah itu menuju batu pamali untuk diangkat sumpah sebagai raja. Selanjutnya Cooley (1997 : 86) Adat serta tradisi merupakan budaya manusia justru menjadi pendukung dimana alamnya manusia Maluku terus terpelihara dan terbina.

Pemukiman (Negeri Lama); Beberapa temuan seperti fragmen gerabah dan bekas pondasi bangunan menunjukkan bahwa situs Negeri Lama Ama Ira merupakan situs pemukiman. Situs ini berasal dari Negeri Aboru Kecamatan Haruku Kabupaten Maluku Tengah.

Menurut informasi dari masyarakat setempat bahwa, situs Negeri
Lama Ama Ira merupakan lokasi pemukiman khususnya bagi Marga/fam Akihary. Karena itu, lahan yang ada di lokasi ini hanya boleh diusahakan oleh keturunan dari marga tersebut sebagai warisan turun-temurun. Adapun fragmen gerabah yang ditemukan merupakan bukti kuat bahwa di lokasi ini pernah berlangsung aktivitas bermukim. Gerabah dipergunakan sebagai wadah, baik untuk keperluan sehari-hari maupun untuk keperluan upacara. Di beberapa situs di Nusa Tenggara Timur, gerabah ditemukan sebagai bekal kubur, dan juga sebagai wadah kubur. Temuan lain berupa bekas pondasi bangunan tidak dapat dipastikan apakah sejaman dengan temuan megalitik ataukah dari zaman yang lebih muda. Tidak diperoleh informasi yang lebih jelas tentang hal tersebut. Diperkirakan bekas pondasi tersebut merupakan bangunan sementara (rumah kebun) yang didirikan oleh salah seorang keturunan marga Akihary. Sedangkan fragmen botol kaca sudah dapat dipastikan bahwa fragmen tersebut berasal dari zaman yang lebih muda, dan bukan diprodusi di Indonesia Karena itu dapat disimpulkan bahwa masyarakat Aboru telah memiliki hubungan dengan dunia luar. Dari ragam tinggalan arkeologis yang terdapat di lokasi Situs Ama Ira, maka dapat disimpulkan bahwa di lokasi ini telah berlangsung beragam budaya yang silih berganti.

\section{KESIMPULAN}

Berdasarkan uraian makalah di atas, maka dapat dapat disimpulkan bahwa :

a. Tradisi megalitik merupakan suatu kesatuan sistem nilai budaya yang berkelanjutan (tradisi berlanjut) yang selalu terintegrasi dalam siklus masyarakat Maluku yang dahulu, sekarang maupun pada masa-masa mendatang.

b. Tinggalan-tinggalan arkeologi sebagai interprestasi budaya megalitik, merupakan simbol integritas dan identitas kebudayaan masyaraka Maluku. 


\section{DAFTAR PUSTAKA}

Cooley, F. 1987. Mimbar dan Tahta. Cooley, F. 1987. Mimbar dan Tahta. Jakarta. Sinar Harapan.

Johnson, Paul Doyle. Terjemahan Robert, M Lawang. 1986. Teori Sosiologi Klasik dan Modern. Jakarta. PT Gramedia.

Kaplan, David \& Roberts A Manners. 2002. Teori Budaya. Yogjakarta. Pustaka Pelajar.

Koentjaraningrat. 1987. Sejarah Teori I. Cetakan Pertama. Jakarta. UI Press.

Sztompka, Pioter. 2008. Sosiologi Perubahan Sosial. Jakarta. Prenada.

Sahulteru, Marlyn. 2010. Penelusuran Jejak Hunian Prasejarah di Daerah Aliran Sungai (DAS) Tala, Desa Tala Kecamatan Teluk Elpaputih Kabupaten Seram Bagian Barat. Laporan Penelitian. Balai Arkeologi Ambon. Maluku-Ambon. Kementerian Kebudayaan dan Pariwisata.

Sahulteru Marlyn. 2007. Persebaran Dolmen Di Saparua. Laporan Penelitian. Balai Arkeologi Ambon. Maluku-Ambon. Kementerian Kebudayaan dan Pariwisata.

Tim Peneliti. 2007. Penelitian Arkeologi di Pulau Saparua. Laporan 